\title{
Cheryl Wall, In Memoriam
}

Edited by Cora Kaplan University of Southampton

\begin{abstract}
The distinguished critic Professor Cheryl A. Wall (1948-2020) was the Board of Governors Zora Neale Hurston Professor of English at Rutgers University, New Brunswick. Her path-breaking scholarship in two highly influential monographs, Women of the Harlem Renaissance (1995) and Worrying the Line: Black Women Writers, Lineage, and Literary Tradition (2005), helped to ensure that twentiethcentury Black women writers were recognized and valued for their power, genius, and complexity. Her most recent book, On Freedom and the Will to Adorn: The Art of the African American Essay (2018), places the essay form at the center of African American literary achievement. Throughout her long career she supported and enabled Black students, and championed racial diversity and gender equality at every level of the university. An Associate Editor of James Baldwin Review, she was the most generous and astute of readers, as well as a wise editor. In this memorial section, fifteen colleagues, former students, and interlocutors share their remembrances and honor her legacy.
\end{abstract}

Keywords: Cheryl A. Wall, Women of the Harlem Renaissance, Worrying the Line: Black Women Writers, Lineage, and Literary Tradition, On Freedom and the Will to Adorn: The Art of the African American Essay, tribute, Rutgers University 


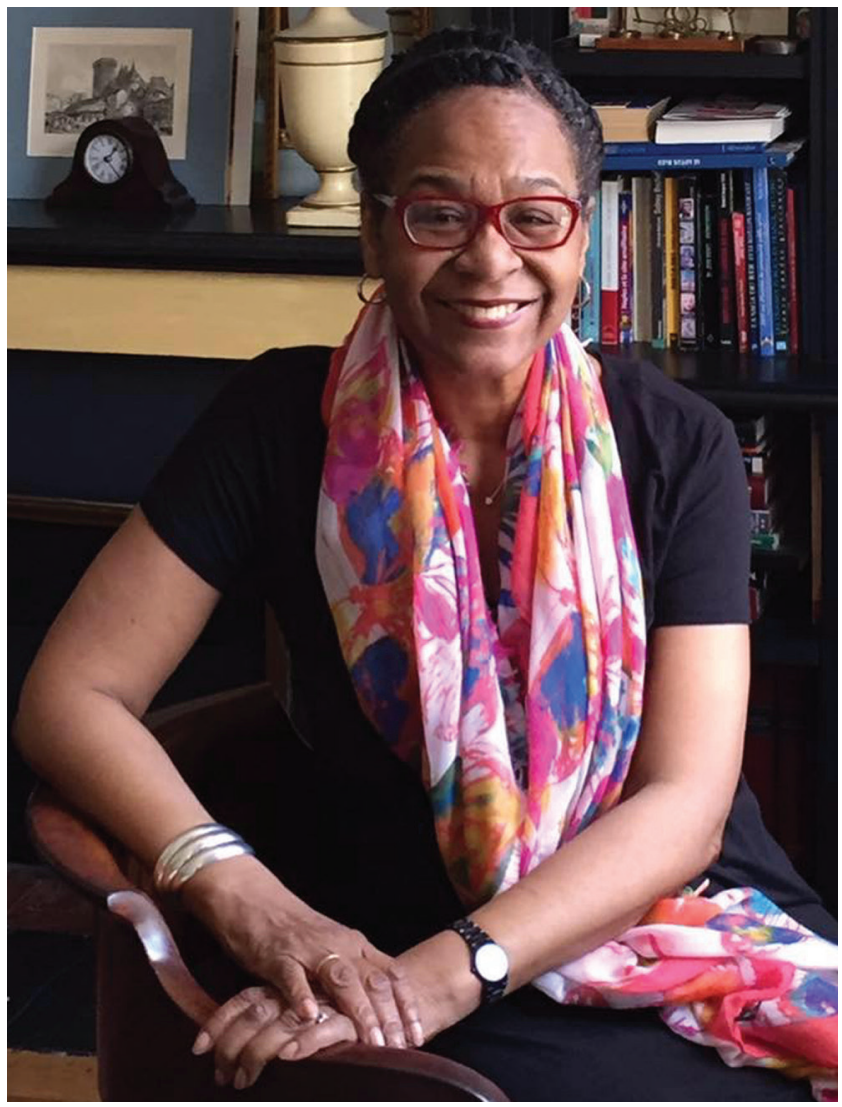

Figure 1 Cheryl Wall (Photograph courtesy of Camara Epps)

\section{Introduction}

Cora Kaplan University of Southampton

We were shocked and saddened to learn of the death, in April 2020, of Professor Cheryl A. Wall, the Board of Governors Zora Neale Hurston Professor of English at Rutgers, New Brunswick. Her path-breaking scholarship shifted the critical conversations about Black women's writing and representation and, latterly, the African American essay. Professor Wall was an Associate Editor of James Baldwin Review, and we will greatly miss her wise, enabling advice and enthusiasm. A symposium in her honor, organized by her Rutgers colleague Professor Evie Shockley to mark the occasion of her retirement, was scheduled for the spring of 2020, but unfortunately deferred because of the pandemic. It is now expected to take place in the spring of 2022, alas without her guiding presence. In the 
meantime, the journal has invited Cheryl's colleagues, students, and interlocutors to remember and celebrate her life and her work. The fifteen moving, personal tributes which are gathered here comprise a collage of vivid portraits that speak of a remarkable thinker and writer, colleague, teacher, mentor, interlocutor, and friend. Praised by all for her generous and collaborative spirit, her intellectual brilliance was matched only by her bold creativity in her field and in her institution.

Born in Manhattan and brought up in Jamaica, Queens, Cheryl Ann Wall was the daughter of Reverend Monroe Wall, a pastor of the Mount Calvary Baptist church in Harlem, and Rennie Ray (née Strayhorn), an English teacher in the city's public schools. She earned her BA in English at Howard University and gained her $\mathrm{PhD}$ in the History of American Civilization at Harvard. She joined the Douglass College faculty at Rutgers in 1972. In the almost five decades of her distinguished career at Rutgers, she was dedicated to transforming and enriching the curriculum, the classroom, and the faculty, making each more racially diverse. She was passionately committed to making the university environment welcoming, supportive, and democratic for students and teachers alike. The generations of postgraduate students whom she mentored, many now professors or educators themselves, speak eloquently of her enormous intellectual generosity and her kindness. Rutgers, New Brunswick, was the destination for an unusually large cohort of first-generation college students, reflecting New Jersey's markedly heterogeneous population. Asked about her vision of the shape and priorities of the "Future University" in a 2016 interview, she responded that undergraduate education should always remain at its center. Encouraging Black students to major in English, and supporting their trajectory at Rutgers and beyond, was at the heart of that practice. Cheryl Wall chaired the English Department at Rutgers from 1997 to 2003 .

One of her first major publications, the edited volume Changing Our Own Words: Essays on Criticism, Theory, and Writing by Black Women (1989), now an indispensable classic, grew out of a conference she organized with others at Rutgers in 1987, in which critics and scholars of Black women's writing came together for "an intense and extended conversation among Black women writers and their readers" to reflect on the "overarching question" of "how to bring the terms criticism, theory and writing by black women into conjunction." In her prescient introduction to the collection, Wall hoped that the productive debates, at the live event and in the book, would, as it surely did, move that conversation on.

In that introduction too, Wall suggested that "from the margins, various strategies may be deployed, and varied, indeed contradictory propositions set forth," and she argued that the differing positions among Black feminist critics was itself a "response to the false universalism" of literary critical traditions that "rendered black women and their writing mute." A major achievement of Wall's first monograph, Women of the Harlem Renaissance (1995), is to move these African American women writers, Jessie Fauset, Nella Larsen, and Zora Neale Hurston, as well as artists and singers, Gwendolyn Bennett and Bessie Smith, from the margins to the center of the Harlem Renaissance where they belonged, and now happily reside. 
Their wider importance to the longer traditions of African American and American writing is revealed both by "locating them in multiple contexts"-the heroine of Nella Larsen's Quicksand in relation to the phenomenon of Josephine Baker for example-as well as reading their work "alongside each other." Zora Neale Hurston's career and work was an abiding interest for Wall, from her first fleeting encounter with Hurston's writing in graduate school. She edited two collections of Hurston's work for the Library of America, as well as two volumes of criticism on her fiction.

The deep connection between the blues and African American writing is caught in Wall's resonant title for her next book, Worrying the Line: Black Women Writers, Lineage, and Literary Tradition (2005), which fast-forwards from the interwar years to the 1970s, coincidentally the beginning of her own career and the moment when an astonishing cohort of Black women writers were transforming the literary landscape-among them Lucille Clifton, Gayl Jones, Audre Lorde, Paule Marshall, Toni Morrison, Gloria Naylor, and Alice Walker. "Worrying the line" is a blues term, here refigured to highlight the ways in which Black women's writing at this conjuncture uses similar strategies of interruption, embellishment, and reworking. It refers simultaneously to the unanswered question of genealogy that arises in the work of so many of these writers, and to the radical re-vision of literary traditions that their writing both consciously pursues and collectively represents.

On Freedom and the Will to Adorn: The Art of the African American Essay (2018) brings the African American essay center-stage as an open and speculative genre in which African Americans excelled, one in which the personal and political are intermingled, and in which form and content are inextricably joined. The study takes a long view of the African American essay and its evolution over two centuries-from the free black Bostonians David Walker and Maria Stewart in the 1820s through Alain Locke, Hurston, Ralph Ellison, James Baldwin, June Jordan, and Alice Walker, to the combined print and online activism of Ta-Nehisi Coates and Brittney Cooper.

In each and all of these densely researched, elegantly written studies, and in her allied essays, Wall reimagined the terrain and the terms through which gender and genre in African American writing were considered. Praising her as a "leading, pioneering scholar," Henry Louis Gates, Jr., cited in Sam Roberts's New York Times obituary, describes the diamond quality of Wall's research and writing as "characterized by the careful meticulous attention to detail of a great literary historian and the exquisite mastery of form that marks the work our best literary critics - a combination all too rare among scholars of American literature today."

Cheryl Wall interpreted "changing words" as both a challenge, "talking back," and as "exchange": the collective and collaborative conversations she enabled with students and fellow scholars alike were essential to the radical research and scholarship she championed and practiced. In her long career she seized her time, found her subject, and helped to shape it. As her colleague Professor Evie Shockley 
has said "when black women writers were publishing, being recovered and receiving national attention in greater numbers than ever before," Cheryl Wall made "a 45-year career of helping to ensure that these writers and their writings are valued in all of their power, genius and complexity." It is now our shared task, to which the eloquent tributes below contribute, to ensure that her extraordinary work, life, and career, embodying in all its aspects what anthropologist David Scott has termed the "receptive generosity" and "the ethics of responsibility" of our most admired intellectuals, is valued in the same way.

\section{Contributor's Biography}

Cora Kaplan is Professor Emerita of English at University of Southampton. She was a General Editor, with Professor Jennie Batchelor, of Palgrave's 10-volume History of British Women's Writing. With Professor Bill Schwarz she organized a major conference on James Baldwin at Queen Mary, University of London, in 2007, and with him co-edited James Baldwin: America and Beyond (University of Michigan Press, 2011). She counts herself privileged to have had Cheryl Wall as a colleague at Rutgers from 1989 to 1995, and as a long-distance friend in the succeeding years.

\section{Remembering Cheryl Wall as Educator and Mentor}

\section{Amy Barenboim Columbia University}

t would be more than possible merely to count and recount the ways in which Dr. Cheryl Wall touched me personally and intellectually. Yet I have found the role Dr. Wall played, and continues to play, in the formation of my time as a young scholar to be a uniquely un-unique story; I am all the time meeting her former students-now graduate students, professors, and educators-who attribute their success to her. I could also detail her pioneering scholarship and countless publications, her work on Zora Neale Hurston and the Harlem Renaissance, and her most recent and last monograph, On Freedom and the Will to Adorn: The Art of the African-American Essay.

However, I want to linger on the interstitial moments of Dr. Wall's time as an educator, moments that will not be revealed in a curriculum vitae or biography. Indeed, in her typical humility, Dr. Wall always described herself as an educator first and a scholar second, working in a long tradition of Black feminist educatorscholar-activists. While waiting outside her office for our meeting one day, I could not help but overhear Dr. Wall with another student, a freshman who had been struggling with her paper for their Toni Morrison seminar. Dr. Wall went through the student's paper line by line, guiding her through grammatical corrections as well as giving suggestions on content. Few, if any, scholars of her stature would take the time to support undergraduates with their writing. 
In the same vein, Dr. Wall was always uniquely attentive to the class dynamics at Rutgers University, where the majority of students are either first-generation college students, commuters, or have full-time jobs in addition to their studies. I observed her understanding toward students in our James Baldwin seminar who would have to miss class for work or to take care of children. As one of the founders of the Rutgers English Diversity Institute, a summer preparatory program focused on creating more diversity in the humanities that brings students from around the country who are interested in pursuing PhDs in English literature, Dr. Wall took special care with students from other states and smaller schools. She took particular care with one student who had come from a college in Mississippi that had a student body of only five hundred people, always checking in with her, sitting with her at meals, and generally making sure she was comfortable in the new environment.

Dr. Wall's scholarly openness also translated into a long line of students, both my peers and students who went before me, who dedicate their work to her and her memory. As a lost undergraduate who wanted to go to graduate school but had no specialty, Dr. Wall encouraged me to study African American literature, welcoming me into a field I felt it was not my place to be in, and setting me on a path I might never have found. My graduate career, and beyond, is due to Dr. Wall's generosity, warmth, and desire to cultivate students who think critically about American history and literature, and who care about democratizing education. As I heard her state many times: "Diversity and excellence are not mutually exclusive."

I recount these moments of Dr. Wall's generosity to show that they were optional; at no point was she required to spend time and energy editing students' writing, mentoring them through graduate school applications, or founding programs to create openings for students of color to become scholars. It was from her own drive, intellectual kindness, and selflessness that Dr. Cheryl Wall dedicated her life to her students.

\section{Contributor's Biography}

Amy Barenboim is a PhD student at Columbia University in the department of English and Comparative Literature. She studies African American and African Diaspora literature and Critical Theory.

\section{To Worry the Line}

\section{Rich Blint The New School}

Tn June 2007, a serious cadre of writers and scholars gathered at Queen Mary, University of London, to mark the twentieth anniversary of James Baldwin's death. This was the first in a series of ad hoc international conferences on the author staged in cities from New York to Boston, Montpellier, and Paris. I arrived 
in the country excited, but a bit harried. I had organized a panel to be chaired by my mentor and colleague, Hortense Spillers, and both of our planes were late. I jumped into a waiting black cab organized by local friends, located the building with some effort, and made my way to the front of the lecture hall. I sat down and gazed at my paper and the conference program while my colleagues (sans Spillers) shared insights about the great man and his work. When my turn came, I began my presentation in the style peculiar to our profession, read a couple of paragraphs, and then stopped. Placing my paper on the table, I quickly took emotional and intellectual inventory, appraising my discovery that this was a concurrent panel in familiar academic fashion. I'm not at all sure what I expected, but I remember pulling up short. I was several years into graduate school and had only seriously studied Baldwin on my own. I suppose that explains it: The growing knowledge that such an intimate relationship as the one I imagined I enjoyed with the author could be shared outside the hearing of all assembled on so solemn an occasion; that considerations of his insurgent legacy could be delivered via such common and well-rehearsed protocols.

I recall saying something to this effect and launching into a kind of missive concerning the relevance of his work beyond the gates of the university. This went over well enough and one of the conference organizers was very kind in her comments afterwards. But it was Cheryl Wall's plenary presentation the following morning that made clear to me how one might properly "worry the line" in relation to Baldwin's corpus. In the context of the condition of contingency and precarity that remains a defining feature of global Black life, scholarly discussions of Baldwin's commitment to a liberatory aesthetics must themselves break pitch, shout, and interrupt conventional narrative procedures. Squarely within the blues tradition that provided the title for Wall's volume on the literary activity of a cohort of contemporary Black women writers, the act of worrying the line is subversive in its insistence on emphasis and clarity. With a voice of quiet authority, a smile that always reached the eyes, and a generous, patient intelligence, Wall brought Baldwin's decades-long quarrel with the deep contradictions of American identity to elemental life. She captured a sense of what bearing witness to the violence raging openly in our intensely racialized society cost Baldwin. One caught a glimpse of the interior damage wrought by always being in battle, of the great burden of assimilating premature Black death-from marquee assassinations to the slow but sure. This was my introduction to the embodied wisdom of Cheryl Wall.

Thanks to the careless misplacement of my luggage by the handlers at Heathrow, my planned jaunt to Paris had to be cancelled. Instead, I had the great pleasure of reveling in Cheryl's convivial spirit through the kind offices of Hortense Spillers. We ate Caribbean food in Brixton, over-priced Italian in central London, and spent hours talking life and politics at the South Bank Centre. The next time I saw Cheryl would be at Vanderbilt University for the inaugural board meeting of Issues in Critical Investigation: The African Diaspora. Convened by Spillers and attracting the labor of first-class intellectuals, Cheryl's 
characteristic wisdom and commitment to clearing a way for the next generation of thinkers was on full display. Over the years, I would witness her subtle redirection of conversation in productive ways, share a stage as she imparted her extensive knowledge on Zora Neale Hurston, and marvel at her remarkable capacity for institution-building.

I saw Cheryl for the last time at the MLA in Seattle last year. She was dazzling with that ready, knowing smile and we enthusiastically agreed to meet for dinner back east. She had only just written to fix a date when I learned she had left us, that her rare beauty, brilliance, and expansive spirit had departed for the celestial. I have to believe that someone like Cheryl who did so much good remains with us not only through her life-shaping impact on students and colleagues. I imagine she must also regularly check on her work, passing through just to make sure no one is messing with her legacy. So then this is how we honor and mourn: In gratitude that she stayed with us long enough to model how to gracefully navigate the actively hostile terrain of the American academy with a transformational intentionality. Like Ursa Corregidora and blues singers before her, Cheryl Wall was possessed by the injunction to sing a song of lineage, to "leave evidence," to worry the line just so and long enough that the life and death gaps in our shared history might yet be sutured.

\section{Contributor's Biography}

Rich Blint is Assistant Professor of Literary Studies and Director of the Program in Race and Ethnicity at The New School. Co-editor of a special issue of African American Review on James Baldwin (2014), Blint is author of the upcoming $A$ Radical Interiority: James Baldwin and the Personified Self in Modern American Culture.

Herb Boyd City College of New York

y personal regard and respect for Dr. Cheryl Wall began years ago, and back
in the summer of 2017 when I was finishing my book on the Harlem Renaissance I turned to her for a blurb, given her scholarship on the subject. "I'm still trying to finish the revisions on my own manuscript-as well as writing tenure and promotion reports for colleagues at Rutgers and elsewhere," was her email reply.

That response was indicative of Cheryl's activity and pursuits, all of which came to an end on 4 April when she died in Highland Park, NJ. She was 71. According to her daughter, Camara Epps, the cause was complications from an asthma attack, an ailment which made her all the more vulnerable in this season of the coronavirus pandemic.

From her post at Rutgers University she was scheduled to retire in May of 2020. Cheryl was widely hailed for her devout commitment to Black studies, 
particularly African American literature with a focus on women writers and the Harlem Renaissance. These attributes were going to be highlighted in a symposium celebrating her legacy that had to be postponed because of the pandemic. "In a period when black women writers were publishing, being recovered and receiving national attention in greater numbers than ever before," Professor Evie Shockley, who was organizing the symposium, said, "Cheryl found it possible to make a 45-year career of helping to ensure that these writers and their writings are valued in all of their power, genius and complexity." More on this can be found in Sam Roberts's obituary in the New York Times (21 April 2020).

Exemplary of her research was the charitable review of Zora Neale Hurston's memoir Dust Tracks on a Road, a book "she did not want to write," Cheryl noted, "and many of her admirers wish she had not written." The book falls far short of a conventional autobiography and is fraught with inaccuracies and contradictions; even so, Cheryl commented, "passages in Dust Tracks are as engaging as any Hurston wrote." In The Oxford Companion to African American Literature her profile of Hurston is nearly definitive.

On the Rutgers University website, Cheryl is listed as the Board of Governors Zora Neale Hurston Distinguished Professor of English and the author of numerous books, including Worrying the Line: Black Women Writers, Lineage, and Literary Tradition and Women of the Harlem Renaissance, and as the editor of Changing Our Own Words: Criticism, Theory, and Writing by Black Women. She was the editor of two volumes of writing by Zora Neale Hurston for the Library of America-Novels and Short Stories (1995) and Folklore, Memoirs and Other Writings (1995) - as well as two volumes of criticism on Hurston's fiction: 'Sweat': Texts and Contexts (1997) and Their Eyes Were Watching God: A Casebook (2000). She was the section editor for "Literature since 1975" in the Norton Anthology of African American Literature (2003). She served on the editorial board of American Literature and on the advisory boards of African American Review and Signs: Journal of Women in Culture and Society.

A former chair of the department, Cheryl remained active in university affairs. In 2003, she was co-principal with Mary Hartman of the Institute for Women's Leadership on "Reaffirming Action: Designs for Diversity in Higher Education." This Ford Foundation-funded initiative examined the strategies higher education institutions successfully employ to enhance racial and gender equity. Most recently, she was selected by Rutgers University President Richard L. McCormick to serve as vice chair of the Steering Committee on Implementation, a body organized to enact sweeping changes in undergraduate education at Rutgers. She had just become co-chair, with President McCormick, of the President's Council on Institutional Diversity and Equity.

She received the Warren I. Susman Award for Excellence in Teaching, and was named a Board of Governors Professor of English in December 2006, and named the Board of Governors Zora Neale Hurston Professor of English in January 2007. Her marriage to C. Roy Epps in 1979 ended in divorce. 
In a follow-up to my request for a blurb, Cheryl wrote: "I'm traveling now, but I'll be home a week from today." She resides now in her eternal home and may she rest in peace.

This piece first appeared as an obituary in New York Amsterdam News on 30 May 2020, http://amsterdamnews.com/news/2020/apr/30/dr-cheryl-wall-distinguished-literary-scholar-dies/ (accessed 16 June 2021).

\section{Contributor's Biography}

Herb Boyd is an adjunct instructor in the Black Studies Program at the City College of New York.

\section{Wesley C. Brown}

T've struggled with how to explain to myself Cheryl's presence in my life and now her absence. Among the words-who, what, why, when, and where-that might help me, the 'who' of Cheryl is the only one I feel I can begin with, though I will, inevitably, fail to adequately answer my question.

There was the first time I met her at my interview for a teaching position at Rutgers University in 1978. I was asked many questions by the English Department faculty. I have very little recollection of what I or anyone else said. But I do have an indelible memory of Cheryl looking at me; and having the feeling that underneath her listening, she was also reading my words closely as I spoke them. That put me at ease, making me aware that she was hearing what I had to say, which encouraged me to want to be heard. I grew to greatly appreciate this quality in Cheryl. It made me more mindful of the importance of becoming an attentive listener in order to expect to be heard.

This probably wouldn't surprise anyone who came to know Cheryl within the community of her nearly five decades at Rutgers. Even while navigating her way through the maze of university life, there was an always unhurried seriousness she brought to her teaching and writing. This was evident in her seminal contributions to the study of African American women writers. Cheryl's commitment spoke across every page of her scholarship, leading us to the thunder in the words of the writers with no need to raise the temperature of her prose. She understood the power of language, giving voice to a generous, open-handed offering to readers, seasoned with a healthy dose of understated attitude and calling up comparisons to song stylist Carmen McRae. To paraphrase Audre Lorde, Cheryl celebrated the kingdom of Black women writers without shouting. And it would not be an exaggeration to say that even her silences were articulate!

I will always treasure our mischievously, often laugh out loud, conspiratorial call-and-response sessions, where we loosened our wits over the literary sweepstakes and the changing/same of the body politic. But despite the loss of those indispensable shared confidences and the failure of words to come close 
to expressing the fullness of 'who' Cheryl was for so many, my grief is made bearable by 'what' memories I have of her that will remain and 'why' the gift of Cheryl's life within my own will be there 'when' and 'where' I feel the need to summon her.

\section{Contributor's Biography}

Wesley Brown is the author of three published novels, a short story collection and four produced plays. He has taught at several colleges and universities, among them Rutgers University and Bard College at Simon's Rock. He lives in Lawrenceville, Georgia.

\section{For Cheryl Wall, My Friend: A Very Short Introduction}

Abena P. A. Busia

\section{The Forty Years}

he railway station, New Brunswick, NJ; this is where we first saw each other. I
was arriving for my interview almost exactly forty years ago, she was waiting to meet me; in those pre-digital, pre-computer, pre-cell or smartphone, nonsocial-media days, two Black women with only our eyes searched along the antique railway platform, and found each other.

There are too many memories.

The following Fall, negotiating the start of the new year at our different Rutgers campuses, our paths seldom crossed naturally. Then several weeks later I got a phone call, an invitation, and another short ride. This time it was to what would have been a "store front" theater in a redbrick factory building lodged in a corner of a parking lot, except there were three risky flights to climb up to reach the makeshift stage. Cheryl had just become the first Board Chair of Crossroads, a new Black theater company in town, and took me to see to one of the bravest performances I have ever experienced: Charles Gordone's No Place to be Somebody (1969). With one generous invitation she introduced me to the world I had entered; a lesson for the ages. I still remember how that experience felt; it made me a believer. Forty years later I am still a subscriber and today on its board of trustees working with the last remaining founder of an organization which, but for her bravery, would never have been established. But for her courage to deal with who we are and where we wish to go there is much that would not have been established. She mentored future scholars at every level, including me.

The field of Black women writers itself! Douglass Library boasts mimeographs of her course on Black women writers, said to be the first in the country back in the mid-1970s when no one even knew our work could constitute a field of study. The first time I myself heard her give a paper, it was the day of an unseasonably 
huge snowstorm at a small conference on Black women writers, one of the first, at a high school in Montclair, NJ. The riches we had in one day; Nikki Giovanni, Toni Cade reading from the draft of Those Bones Are Not My Child, and the great Gwendolyn Brooks, reading and being Miss Brooks. The two critics among the writers were Cheryl A. Wall, who was fully present and spoke elegantly and wisely, and Hortense Spillers, but Hortense had been caught in the storm. She walked in late, but right on her closing presentation cue, still impeccably dressed with her short natural hair, and delivered a most perfect concluding talk, like she had been listening in on all the conversations, including Q\&A, though she had missed the entire day. Once again Cheryl was driving, in a raging blizzard; we had dinner with Hortense at the long since disappeared Wooden Nickel before she continued on in the storm back down the turnpikes to Haverford.

Cheryl was working on The Women of the Harlem Renaissance and our vision of that world has never been the same.

I wrote my poem "Liberation" that very night: "we are all women, and we have that fire within of powerful women who can laugh beauty into life, and still make you taste the salt tears of our knowledge."

I remember our two mothers in Cheryl's first married home on Seaman Street; Mother Rennie Strayhorne Wall lifting her granddaughter into my once midwife mother's lap the week after the birth of Camara Rose. We had come to honor the ceremonies of the eighth day, bringing mother and daughter something white to mark her arrival and stay on this earth.

About a decade and a half later, standing in the parking lot of Murray Hall, with Cheryl uncharacteristically exasperated with that one and only child, refusing to be placated by Sharon Lewis's attempt to console her that the current adolescent storm was just the hormonal season, the three of us bursting into laughter at Cheryl's characteristic riposte both fierce and funny: "I had hormones, you had hormones, we all had hormones, but not in my mother's house!" Mother Cheryl Lena Younger Wall: "In my mother's house there is still God."

And another decade after that, Cheryl in my mother's house in Accra: she really did see us at home, mother with her two granddaughters playing at her feet, bridging that gap, what a joy! She broke bread in my house in Ghana as I had during so many conversations around pot luck at her kitchen table, or the cornucopia that was her family Thanksgiving table; Cheryl, sister, and daughter hosting an assemblage of folks such as me, my waif and stray daughter, their fatherless nieces, and her ex-husband's great aunt.

We shared so many moments; marriages, divorces, present and absent daughters, the labors of creation; unfinished projects, half-finished books, awardwinning publications, including invitations to the White House, all of it discussed and lauded around that small kitchen table. Or across her office desk.

She had way of looking over her glasses when she sensed you (or I, at least) were on the verge of saying something questionable, then lifting them onto her head when the look hadn't been enough to stop you-before sighing slowly and saying 
gently, "Well you know, you might want to reconsider that." When Cheryl suggested I might well want to reconsider something, I sat myself down and reconsidered!

And I don't think she ever understood how the friendship and love never diminished the admiration and the awe.

To this day I like to read her words aloud, I always have, because to do so is to hear the arc of her voice in the fine scan of her prose; a piano player's phrasing, each paragraph a musical score.

I have missed her more than I would have anticipated these last three years away. I took for granted the ability to knock at her office next door, or just cross the river to sit on her front doorstop and wait for her to come home.

And she will never come to that home again.

\section{The Forty Days}

Saturday 4 April 2020, 9:00 p.m. Brasilia time; my bedroom, after dinner a phone call from Stefan and the unendurable counting started.

Wednesday 8 April 10:00 a.m. Brasilia time, five grieving days later; an English department meeting over an unstable zoom connection; in these days we cannot meet to touch, I am grateful just to join colleagues in what is the only ritual of remembrance I can share, of this friendship guarded so jealously for four decades; to hear someone say they too loved you, and be comforted.

Saturday 11 April, Brasilia: the cycle of seven days of absence completed. Were I at home in Ghana, or you a Ghanaian anywhere in the world, family and friends would gather, pour libations, sing hymns, celebrate your life. Instead, I rattle distracted around this house, empty-handed, broken-hearted, leaden-footed. "What ceremony else?"

Thursday 17 April, thirteen days: I should have been at Rutgers today for the symposium honoring "the enduring legacy of your work." Is it blasphemy to say the timing was churlish? To ask the good Lord what it is He had in mind? We wanted just two more weeks to throw you your lifetime achievement party! That the date had already been moved six months is an inconvenient COVID truth we will let pass. You called to say you hoped I could still come; as if there were ever a question.

Wednesday 14 May: today the forty days are over. Your soul must be unfettered to reach home. Stefan had written "In these already trying times, we will have to find new ways and forms of grieving," so it is he and Evie I contact to confess I haven't been able to sleep a single Saturday night in April. Grief is a strange devouring beast: we find new forms of appeasement, we exchange your own words, and read other words of mourning: I offer "I Am Standing Upon the Seashore" and wonder what it was like for you; who were the "other eyes watching ready to take up the glad shout Here she comes" at your dying? 


\section{Coda at Forty Weeks}

As this new year turns,

Sad is not the word for what I am

as I struggle to fix these memories,

for you are free now:

Through your will to adorn everything about this life, you have worried all the lines to savour the salt of your lasting renaissance.

Consider these patches of memory

the distressed funeral cloth I could not wear for you,

its erratic lines of mourning

the white threads of repair stark against

my indigo cloth of grief.

Let's re-write this casebook for the blues:

This first year your anniversary falls on Resurrection Sunday.

I will wear white and remember you

With Love.

\section{Contributor's Biography}

Abena P. A. Busia, Ghana's current ambassador to Brazil, was Cheryl Wall's colleague at Rutgers for forty years. She has published widely, lectured extensively, and taught workshops and master classes on curriculum transformation in the areas of gender, race, and African Diaspora studies. She is also a published poet and one of the three project co-directors and series editors of the award-winning four-volume Women Writing Africa project, published by the Feminist Press (2002-08).

\section{"I'Il Change as Many Words as I Darn Well Please": Tribute to Cheryl Wall}

\section{Cheryl Clarke Rutgers University}

Who said we had to call ourselves "African-American" instead of "Black?" Nobody asked me.

Cheryl A. Wall, c. 1989

$\mathrm{T}$ he chronological approach would take almost fifty years of memory. And there's only so much memory and only so many words. (I am already over my word limit.) Cheryl Wall was of a generation of Black feminist thinkers who, in their writing and their teaching, heralded the brilliance of African American 
women writers. Cheryl and I ended up in the same institution, Rutgers, that was intent upon being in the running with US university literature departments championing the literature of African Americans (men), and if Black women must be among them, then so be it. (Though when I first entered Rutgers in 1969, only one faculty person, Walter Bezanson, had even heard of Bessie Smith.)

I first met Cheryl Wall in 1972, when she moved to New Brunswick, NJ, where I had lived since 1969. We were, in fact, both graduates of Howard UniversityCheryl in 1970 and I in 1969. And we lived in the same shabby high-rise apartment building, Bishop Towers, overlooking the banks of the Raritan River. (And best of all, the bus line to Manhattan stopped right in front of our building every hour.) We shared the same spelling of our first names, after pre-baby boomer Cheryl Crane, Lana Turner's fated and fateful (lesbian) daughter.

Cheryl was among a number of Black and white faculty who caused progressive changes in the curriculum, culture, color, sex, and faculty of the Rutgers English Department. Cheryl was a scholar, teacher, preacher's daughter, and gentlewoman. She laughed easily. Her laugh was affecting and infectious-characteristically cupping her hand over her chuckling. We had many years of conversations on Black literature: from Wheatley to Wright, Harper to Harper, Walker to Walker, of Amiri Baraka and ntozake shange, of Toni Morrison and Toni Cade Bambara, of Gwen Brooks and Ann Petry, of Nikki Giovanni and Maya Angelou (neither of whom are my favorites, nor Cheryl's).

Cheryl introduced Toni Morrison the first time she came to Rutgers to speak in 1973-after her first novel, The Bluest Eye, and just before the publication of Sula. In her days as a summer intern at Random House, Cheryl had known Morrison, an editor. Cheryl was among the first people to whom Morrison showed the galleys of The Bluest Eye-such was the charisma of Cheryl and such was her brilliance. Morrison came to Rutgers many times after 1973, and Cheryl was always close at hand to make her more at ease. Shortly after Morrison's death, when we talked on the phone, Cheryl said, "Even though I had been told for the last year Toni was very ill, I found it hard to accept her death. We think some people will be here forever." We do think that, Cheryl. Then, with such suddenness and finality, there you were-not here. No chance to go back. No time for a grudging last profession of affection. No occasion for a halting admission of some youthful nonsense. And the finish. And then that "Girl. Girl. Girl" Sula-Nell moment.

I am remembering the four-day conference, "The Black Woman Writer and the Diaspora," convened in 1985 in East Lansing at Michigan State University. In her closing remarks, Akasha (Gloria) T. Hull says the conference pulled together "black women writers, critics, readers from our various places throughout the world-particularly Africa, the Caribbean, and North America-so that we could share our love of our selves [sic] and our writings with one another" (The Black Scholar, March/April, 1986, p. 2).

Toi Derricotte, Jewelle Gomez, and I drove there from New Jersey. Cheryl was there as well, and in fact had also driven from New Jersey with Abena P. A. Busia. 
(They drove back to New Brunswick with critic Hortense Spillers, who drove on from there to Haverford, PA.). We were there with the likes of Maryse Condé, Audre Lorde, VèVè Clark, Alexis De Veaux, Ellen Kuzwayo, and many other luminaries whose names I cannot remember. Cheryl and I first encountered one another at the book display tables, where I was selling Conditions Magazine, which I co-edited at the time. This was one of the most transformative experiences of my life, because of the panoramic vision shone upon the diasporic oeuvre of Black women. Cheryl and I continued to bump into one another happily for the duration of the conference. Every time calling out to one another: "Cheryl Clarke." "Cheryl Wall." "Cheryl Wall." "Cheryl Clarke."

"Changing Our Own Words: A Symposium on Criticism, Theory, and Literature by Black Women" in 1988 was and is one of my most satisfying experiences as a Black feminist at Rutgers or anywhere else. As organizer, Cheryl assembled her planning committee, which included an energetic crew of faculty, deans, graduate students, administrators, and a wonderful visiting scholar. Cheryl's acknowledgments in Changing Our Own Words: Essays on Criticism, Theory, and Writing by Black Women will give readers an idea of how stupendous a symposium it was.

I was involved with "Changing Our Own Words" because I was Cheryl's friend and believed in the project. I also wanted to stand up for Black lesbian writers as actors in the African American tradition and as resisting its respectability strictures. I did my best. This one-day event was radical for the intelligence that it radiated, though the issue of sexuality was not addressed explicitly. Mae G. Henderson, Deborah E. McDowell, Valerie Smith, Hortense J. Spillers, Hazel Carby, Claudia Tate, Abena P. A. Busia, and Susan Willis made marvelous contributions, exploring and exploiting language, form, history, and genreredefining Black women's writing and literary criticism in a Black feminist image. Two years ago, at a colleague's retirement party, Hazel Carby, whom I had first met at "Changing," expressed to me that it remains an unforgettable experience for her.

Cheryl Wall chaired my dissertation committee (1996-99). We had been having conversations about Black literature for almost thirty years by 1999. So they (the conversations) might as well have culminated in my dissertation defense. Cheryl disagreed with me unrelentingly over my opinion of ntozake shange's for colored girls (who have considered suicide when the rainbow is enuff) as a closeted exploration of lesbianism in the "black community." I still think it is. And Cheryl never changed her mind.

Cheryl delivered a remarkable talk on Black bibliophiles at the "Black Women Writing across Genres in the Late 20th Century" symposium at Penn in February 2020, to which we had both been invited. Organized by Professor Barbara Savage and Senior Curator Lynne Farrington, we were called upon to celebrate the gift from Ms. Joanna Banks of 5,000 books by Black women writers to Penn's Van Pelt Library. Cheryl's talk placed Ms. Banks, a Black lesbian collector and Baltimorean, 
in the school of Black bibliophiles who, unlike their (Black bibliophile) predecessors, including Arthur Schomburg, did not "apologize for" but rather extolled the African American literary tradition. After that lovely symposium, Cheryl and I taxied to the famed 30th Street Station in Philly to catch the Amtrak back North. Unable to sit together, we parted, and I watched her back as she proceeded to another car. She detrained at the Metro Park, NJ, station, and I rode on to Penn Station in Manhattan. Two weeks later, masks descended over New Jersey, New York, and the rest of the country. Then that April morning, Barbara Balliet, my partner of 27 years, who knew Cheryl from Rutgers and Women's Studies (19902013), haltingly, thickly announced, "Something terrible has happened." She held out the Facebook post on her iPad. I took it to my breast as to either squelch or to let its pronouncement seep into my weak heart. I had no words. And barely any breath.

A year ago now, in Philly, the night before our panel, I saw you from the street at the front desk of the Hilton Inn at Penn. I was foiled at surprising you. You knew I was approaching and called me out: "Cheryl Clarke," you greeted, bending over your signature left hand, un-turning. "Cheryl Wall. I shoulda known I couldn't sneak up on you," I confessed.

Xmas of the year we met, 20,000 tons of bombs exploded over Hanoi. One-stress last names. Clarke. Wall. One, common Irish; one, blurry conceit. A resonance of uplift. "New Negroes." Postwar. Howard co-eds. Black Arts. The "race's" literary sophistication declaimed unabashedly to each other all night in those early days: "Listen to this ... Hey. Listen."

\section{Contributor's Biography}

Cheryl Clarke is a Black lesbian feminist poet and the author of five books of poetry: Narratives: Poems in the Tradition of Black Women (1982), Living as a Lesbian (1986), Humid Pitch (1989), Experimental Love (1993), and By My Precise Haircut, winner of the 2016 Hilary Tham Award from Word Works Books; and of the chapbooks, Your Own Lovely Bosom (2014) and Targets (2018). With her life partner, Barbara Balliet, she is co-owner of Blenheim Hill Books, a used and rare bookstore in Hobart, NY, and she maintains a teaching affiliation with the Graduate Faculty of the Department of Women and Gender Studies at Rutgers, the State University of New Jersey.

\section{Remembering Cheryl}

Paula J. Giddings Smith College

There are people you like right away; you know, as soon as you meet, a steady five decades ago. 
We were of the same generation, experienced the same thrills when the likes of Toni Cade Bambara, Alice Walker, and Toni Morrison came on the scene to feed our hungry souls. Over the years we were impressed by each other's work too. But there was something else.

I think (we actually never talked about this) we shared an emotional makeup that was impassioned but disciplined-maybe even a little repressed-by the insistence of humility hammered into us as children. With me, Cheryl could brag a little and know that I wouldn't take it the wrong way, and vice versa. I can still see one of those can't-help-myself smiles in the telling of her triumphs over grad-school doubters at Harvard; of Toni Morrison choosing her to present a paper side by side with her at an important forum; and my favorite, the time when the then president of Rutgers, in an effort not to lose Cheryl to a competitor, sent a limousine and driver to her house with a counter-offer that couldn't be refused. I especially liked to tell these stories at gatherings with self-congratulatory talk and where Cheryl was demurely silent.

We both had a kind of wild-child-dying-to-get-out syndrome, tame by today's standards, but which we were able to realize, in part, when we rented an apartment one summer in Harlem. We threw parties featuring our specially made, multiliquored Sangria, and got great satisfaction from the fact that its storied effect on our guests made us a little infamous in our group.

One day I was reading a newspaper over lunch and saw that Aretha Franklin was to feature at the Newport Jazz Festival and in fact was singing that very evening. No words were spoken, we just got up from the table, tumbled into my old Rambler (which sometimes required the passenger to use a stick to raise the accelerator that could get stuck) and made our way to Rhode Island. We decided not to tell anyone who might worry about us until we got there. There had been a lot of angry protests at the festivals in past years and we didn't want to chance an order to desist.

Cheryl and I didn't even think of reserving a place to stay the night, or even checking if there would be tickets available. We weren't even sure we would arrive in time to hear the Queen.

I remember how balmy Newport was and the beauty of the ocean. I remember that Cheryl and I somehow got tickets and got to the concert just in time to hear Aretha. I remember at that moment that was all that mattered.

\section{Contributor's Biography}

Paula J. Giddings is the Elizabeth A. Woodson Professor (Emerita), Africana Studies, at Smith College. She has published four books, including Ida, A Sword Among Lions: Ida B. Wells and the Campaign Against Lynching (Amistad, 2008)winner of the Los Angeles Times Prize in Biography, the Letitia Woods Brown Prize from the Association of Black Women Historians, and a finalist for the National Book Critics Award. She is a member of the American Academy of Arts and Sciences. 


\title{
Passing the Torch, Sharing the Light
}

\author{
Melanie R. Hill Rutgers University
}

Tn Scripture, the latter set of verses in Proverbs assert, "She opens her mouth with wisdom and the teaching of kindness is on her tongue." As my gracious mentor, Dr. Wall, you were the definition of God's love and all of its attributes; you were patient, benevolent, attentive, altruistic, and compassionate. In 2020, the New York Times aptly named you "Champion of Black Literary Writers." As my mentor, though, you were more than a champion whose erudition, life, and legacy continue to envision the world not as it is, but as it should be. Comporting yourself with grace, humility, and dignity, you were the model and ingenious embodiment for so many Black women literary scholars. In your book, Worrying the Line: Black Women Writers, Lineage, and Literary Tradition, you mark the blueswoman as a figure who is not only represented in the works of contemporary Black women writers but who also uses her life's creativity to empower others. The blueswoman's art enables others' work and creativity. Just as the blueswoman in your work empowered others, your work and life, Dr. Wall, have also empowered me. By passing the torch and sharing the light, you were affable in your mentorship.

I officially met you in 2018 while I was a postdoctoral fellow at Rutgers University. You took me under your wing, and you always had a listening ear for me. As I approach the first year since your passing, I hold your material culture even closer to me, both literally and figuratively. Your material culture, encompassing the depth of Black women writers, defines the newfound imprint and legacy you have left in my life and the guiding light for my career.

There were several times when you and I would unexpectedly appear at the same events. In the spring of 2019, we met at the Toni Morrison reading at $92 \mathrm{Y}$ in New York where Phylicia Rashad and Andre Holland were reading from Morrison's The Source of Self Regard. Surprisingly, while I was waiting for the event to start, the elevator doors opened and you appeared! A few months later in October 2019, New Jersey convened a Crossroads Gala honoring Denzel Washington. After the event was over, I was preparing to leave and suddenly you were right in front of me! There were other events, but for these, each time I saw you, I exclaimed with glee and was so happy to see you.

Dr. Wall, because of your example, I know how to comport myself and be the best professor that I can be. I knew that any advice that I would need, I could call and talk to you without hesitation. In 2018 in Atlanta at the National Women's Studies Association conference, I remember you admiring a renowned author after the keynote address. As we both stood toward the front after the event, you said, "This author is the most centered woman I have ever seen or experienced." The same centeredness that you admired in that author, I also admired in you. I can still hear the tranquility in your voice and the cadence and intonation of joy in your laughter. Your father, Reverend Monroe Wall, was a Baptist preacher, so we were able to bond intellectually over my research interests of literature, music, and theology. You knew the art of the sermon, so you were able to speak with me about 
my passion and work on Black women preachers, musicians, and how the art of the sermon manifests through literary, musicological, and theological realms. You were able to discuss that in-depth with me, and I will be forever grateful to you. I miss you so much. You were also a huge fan of the Queen of Soul, Aretha Franklin. We both had a deep love for her sacred music:

When our work here is done,

And the life's crown is won

And our troubles and trials are o'er

All our sorrow will end

And our voices will blend

With the loved ones who've gone on before...

in the land where we'll never grow old.

As Aretha Franklin sings these lyrics so mellifluously, I think of your work, legacy, and what you left with me. I know that you will be a constant guiding light in heaven for us all.

I always say that it inspirits me now more than ever to continue to do the good work my soul must have. Two weeks before you passed, I shared good news with you, and you said to me, "When this pandemic is over, we're going to go out and celebrate!” Although our dinner celebration never came, I celebrate you, Dr. Wall, through my work and my passions of literature and music. I celebrate the beautiful mentor that you were to me. I celebrate your gentle spirit. I celebrate you welcoming me with open arms. I celebrate our mutual love for Aretha Franklin. Through your life, you have taught me what it means to value the work that fuels me. I miss you tremendously, and when I'm confronted with a situation, I always ask myself, "What would Dr. Wall do?" or "How would Dr. Wall respond?” With your books in one hand and a violin in the other, I honor your legacy, Dr. Wall, today and forever!

Love,

Melanie

\section{Contributor's Biography}

Melanie R. Hill, PhD, professor, scholar, and gospel violinist, is an Assistant Professor of American Literature in the Department of English at Rutgers University, Newark. Her research examines the intersections of African American literature, music, and Black theology.

\section{Ricardo Khan}

$\mathrm{B}$ efore this all there was was one crazy notion.

An idea, a new view, of ourselves imagined so differently. 
It was a bridge too far for too many. But we hadn't the restraint of imagination some thought we should have, nor the appetite to sit at someone else's table when we knew we could manage the meal ourselves.

We didn't know any better!

And in the swirl and glow of our own young, Black impatience, with dream in hand and uncaring of what might lie ahead in our way, we were introduced to the precious soul who would become our first Co-dreamer,

Cheryl A. Wall, Crossroads Theatre Company's first Board President.

It would have been easier for a soul of sane mind to say, "Nice dream, fellows, keep it up and keep in touch." In fact, most did. But not Cheryl Wall. With Cheryl, it was "I hear you, I'm with you." Simple. Full stop.

It would have been easier to walk away. But people like Cheryl wouldn't ... couldn't. For even back then, she seemed to know something of what she was meant to do and be to us on this earth, in this dream. After all, she was a brilliant mind.

The Crossroads Theatre Company is here today because in its first days, when some listened interested, Cheryl Wall listened and responded fiercely! No bravado, no leader's pride, no raised voice, no fear.

Just the souls of Black folk pounding in her heart.

\section{Contributor's Biography}

Ricardo Khan is a director, writer, and the co-founder and Artistic Director Emeritus of the Tony Award-winning Crossroads Theatre Company. Recently, Khan produced and directed the opening night ceremonies for the Smithsonian's new National Museum of African American History and Culture in Washington, DC, and wrote the NAACP award-winning FLY, about the Tuskegee airmen of World War II.

\section{Today, My Gratitude Looks Like Grief}

\section{Brian Norman Simmons University}

$\mathrm{W}^{\mathrm{i}}$

hat I remember is the music.

In her graduate seminar on the African American essay, Cheryl Wall began each session with an offering from the Black song book as we filed in. Billie Holiday, Nina Simone, Thelonius Monk. Before we opened a text to peer inside with any theoretical instruments at hand, we entered a cultural space as a community 
to honor the beauty and import of language, stories, and the history and experiences from which they came. This is what it meant to take literature seriously. Looking back, that seminar room in the basement of Murray Hall at Rutgers University was something of a version of James Baldwin's welcome table.

"The African American Essay" was the very first course of my graduate career. I was a first-generation college graduate and a queer white kid from smalltown Oregon who wasn't quite sure what I was in for when I decided to pack up my life, drive across country, and pursue a PhD in literature. Dr. Cheryl Wall was also the very first Black teacher in my entire educational career-a deficit I have spent my subsequent career correcting. Dr. Wall quickly became my image of intellectual authority and how to do literary study with rigor and integrity. Later-after much effort on my part, and grace on hers-she became my advisor. Eventually, I would come to call her Cheryl. Still, as Dr. Wall, she remains my model of an academic life well lived, as she is for so many others.

I consider myself deeply fortunate to have studied the work of Baldwin under Cheryl's guidance. With patient, skeptical questions, she pushed me to go beyond facile understandings of Baldwin's portrayals of sexuality in his fiction and examination of race in his essays, or his contested role as a public voice of a Black freedom movement that didn't always welcome him. With care, she illuminated the American project of identity and democracy undergirding all of Baldwin's writing and helped to place him in an American intellectual tradition with Black experience, traditions, and lives at the center.

Cheryl's writing on Baldwin-like her work on Black literature generally-is marked by a clarity of language and depth of insight born from a lifetime devoted to genuine understanding. I continually return to some enduring lessons. Her fundamental insight that the will to adorn is an expression of freedom is a stunningly apt explanation of African American artistic expression, in all its beauty, joy, and pain. Her use of the blues practice of "worrying the line" to explain artistic adaption in Black women's writing is a brilliantly clear conception of how literary traditions work. In all her work, Cheryl cut through the intellectual debates of the time to find the distilled wisdom of the work itself, which in turn reframed the entire debate. That is one reason why when Cheryl spoke, everyone listened.

Cheryl understood how to build an academic field devoted to Black literature. There is an entire generation of scholars who can call Cheryl their mentor. As a white scholar, I am particularly humbled that Cheryl extended the patience and trust that cross-racial mentorship requires. It is not lost on me that it was through Cheryl that I first encountered Baldwin's reflection in The Fire Next Time on the formative role of Orilla "Bill" Miller, his early white teacher. When the time was right, Cheryl would introduce me to key thinking by Black women that I needed to know about, such as "Naming the Problem that Led to the Question, 'Who Shall Teach African American Literature?"' the famous PMLA essay by Nellie McKay, another Black woman scholar we lost much, much too early. Cheryl made a place for me in a field she helped build, and she helped me 
understand my responsibilities and my limits. She didn't have to do this. My world is bigger for her generosity.

I learned of Cheryl's passing from a friend and fellow mentee. We were gutted by the loss and its abruptness. A diaspora of friends, colleagues, and mentees had been set to convene for a symposium on Black feminist literature on the occasion of her retirement and in honor of the field that she helped build. But those plans had just been scuttled by the early days of the COVID-19 pandemic. Now, it was a fundamental injustice that we would not get to give Cheryl her flowers, that day or ever. Instead, the diaspora had to gather in grief from afar-in phone calls, on social media, in elegies - to try to find words to mark the loss and what Cheryl meant to us, and the world. Here is my own offering from that day:

Let us hold up Cheryl Wall today. She was a towering intellect, gracious soul, and generous mentor to so many, including me. She shaped worlds. Today my gratitude looks like grief. Rest well, Professor.

\section{Contributor's Biography}

Brian Norman is Dean of the Gwen Ifill College of Media, Arts, and Humanities at Simmons University where he is also Professor of English. His most recent book is Dead Women Talking: Figures of Injustice in American Literature (Johns Hopkins University Press, 2013).

\section{Claudine Raynaud University Paul-Valéry Montpellier 3}

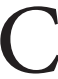
heryl A. Wall was scheduled to take part in the Toni Morrison symposium that we were organizing at the University Paul-Valery in Montpellier in March 2020. Her talk would have been entitled “Toni Morrison's Sublime Word-work," a wording borrowed from Morrison's 1993 Stockholm lecture: "Word-work is sublime [...] because it is generative: it makes meaning that secures our difference, our human difference-the way in which we are like no other life." The global pandemic decided otherwise, but word-work is what Cheryl Wall and all of us, scholars, writers, critics, are indeed engaged in, and all the more so in these harrowing circumstances. Amid a mounting feeling of disarray, helplessness, and incredulity, we had to reschedule the conference when the news came in the mail in early April that Cheryl had passed away. The shock was immense to our community of Morrison and African American scholars and to me especially, since we had last talked at the CAAR Zora Neale Hurston conference in Orlando the year before. I last saw her in Eatonville, FL, Zora Neale Hurston's hometown. The Montpellier conference, which finally took place in September 2020, both via videoconference and on-site, paid homage to Cheryl, whose major book on the black female literary tradition, Worrying the Line. Black Women Writers, Lineage, and Literary Tradition, was mentioned on the call for papers. Her work was a prism through which we wanted to revise our readings of Song of Solomon. 
Our first meeting was in 1991, at the University of Tours, when I invited her to one of the first conferences I organized upon my return from the United States, where I had studied at the University of Michigan. Michel Fabre and all the French African American university researchers around him that made up the CEAA gathered, as we would until his death in 2007 (Voix éthniques, Ethnic Voices. GRAAT \#14, 1996). She came with Mae Henderson and we spent a lot of time at the local police station, since Cheryl had been robbed at the railway station. She was laughing to have been caught unawares in a small provincial French town, when she was so streetwise in the urban metropoles of the United States. This event started a lifelong relationship with both scholars, whom I would meet on sundry occasions in Europe or the United States. Cheryl was working at the time on what would become Women of the Harlem Renaissance, her path-breaking feminist contribution to the scholarship that was then thriving in a reassessment of that crucial period for Black pride and artistic achievements. Her meticulous scholarship placed Black women writers at the forefront, as she categorically asserted that "the Harlem Renaissance was not a male phenomenon." Marita Bonner, Jessie Fauset, Nella Larsen, Zora Neale Hurston, Georgia Douglass Johnson: all these women writers would gain prominence and visibility thanks to her intervention, and the appraisal of the Harlem Renaissance was changed forever, as was the scholarship that followed in her wake.

She had been a pioneer in Black feminist literary criticism (along with Barbara Christian, Deborah McDowell, and Mae Henderson) with her book-length study, Changing Our Own Words: Criticism, Theory, and Writing by Black Women. She was a key figure in that field, "troubling" established truths, "worrying" a tradition. Her last book, On Freedom and the Will to Adorn: The Art of the African American Essay, addresses the African American genre of the essay in which so many Black writers have illuminated themselves: Baldwin, Ellison, June Jordan, and Alice Walker, but also the new generation, Ta-Nehisi Coates, Brittney Cooper. Her decisive contribution definitely alters the appreciation of generic categories in the African American literary tradition.

Cheryl Wall, whose professional title was Board of Governors Zora Neale Hurston Professor of English at Rutgers University, went on to edit the two volumes for the Library of America (1995) that gather Zora Neale Hurston's works, in which she incorporated the unedited version of Dust Tracks on a Road, which I had analyzed as part of my PhD dissertation at Robert Hemenway's suggestion. She also co-edited two volumes of articles on Hurston's Sweat and her celebrated novel Their Eyes Were Watching God. Analyzing Hurston's contribution to Black literature and culture was a link that joined us across the Atlantic, for one needs other kindred spirits, benevolent mentors, thinking partners, in order to move forward. A community of scholars.

Our paths crossed multiple times over the years. I, for instance, vividly recall meeting her in London at another scholarly event, a Baldwin conference at Queen Mary University in 2007, where Caryl Philips was also guest speaker. When I applied for a Zora Neale Hurston visiting professorship at the University of 
Central Florida, I turned to her to write a recommendation letter. I am so thankful for her support, her kind and generous words. As I carry on working on Hurston, I am wondering to whom I should now turn to read and critique my work. Thoughts of Cheryl come up and I see her face in my mind. And I feel the pain of loss, the pang of mourning. Cheryl was an accomplished scholar, a trailblazer in Black feminist literary criticism, a shaper of the tradition of Black letters. She was also a kind, beautiful person. I miss her.

\section{Contributor's Biography}

Claudine Raynaud is Professor Emerita of American Studies at University PaulValéry Montpellier 3 and W. E. B. Du Bois Fellow (2005). She recently published a translation of Sojourner Truth's Narrative (PURH, 2016), and "The Uses of Enchantment: Instances of Magic Realism in Morrison's Later Writing," in The Palgrave Handbook of Magic Realism in the Twenty-First Century (2020).

\section{Tribute for my Mentor, Professor Cheryl A. Wall}

\section{Heather D. Russell Florida International University}

\footnotetext{
$\mathrm{C}$
} heryl Wall oozed Black literary tradition and she suffused us with it. By "tradition" I am not speaking of the kind imposed on and used against Black scholars during the culture wars, the "nagging" word we were warned of in 1972 by Mary Helen Washington-the word which "has so often been used to exclude or misrepresent...." Tradition for Dr. Cheryl Wall was about respect for the vexed, complicated, and vanquishing history of more than two hundred and fifty years of Black letters, the profundity of a body of work that didn't just come up all willy nilly. No solitary solipsistic masturbatory writing here. Black literature, criticism, and theory in and as community-that is how she trained us.

I was fortunate to enter the MA/PhD program at Rutgers in 1991 as one of a cadre of young Black graduate students (four ahead of me, two of us contemporaries, and perhaps another five admitted in the subsequent two years) who formed, I now realize, a safeguard against the then en vogue of all things African American studies. We were the stealth weapon against the potential dilution, diffusion, and dismissal of a field still young, tenuous, and precariously placed within the ivory halls of the academy. Two years before, Cheryl (and I did not dare call her "Cheryl" until the end of my first year, and only with her permission) had published the germinal Changing Our Own Words: Essays on Criticism, Theory, and Writing by Black Women. That collection was as important to many of us emerging Black feminist critics as the publication of Toni Cade Bambara's The Black Woman (1970) had been to Black women writers, activists, and newly minted Black and Women's Studies scholars nearly two decades before.

Changing Our Own Words gave us the critical taxonomy we needed and eventually learned to wield-Mae Gwendolyn Henderson's heteroglossia/glossolalia 
(or speaking in tongues), Spillers on Freudian theory and race, Wall on "changing words." Theirs was discursive armor in the incredibly alienating hypertheoretical world of Foucault, Derrida, and Lacan, where many of us sat wondering when or where we entered. Impostor syndrome had not yet been coined. At her home, Cheryl hosted monthly gatherings for the Black graduate students in English. There we could laugh, cry, drink, signify, specify, and give the lie to the idea that we did not belong. The year I began studying for my comprehensive exams, which originally were to comprise four approved bibliographies (major author, genre, theory, and a hundred-year historical period), we were told that the graduate faculty had instituted a significant change. If we wanted to focus on African American literature as our historical period, we would be expected to know more than 250 years of it. We would need conversance from Wheatley to Wideman. We complained to our Black professors, Cheryl Wall, Donald Gibson, Abena Busia, and Wesley Brown, only to learn that they had led the initiative. Of course, they had.

On the first day of my first graduate course in African American literature, a class jointly taught by Cheryl and Dr. Gibson, I vividly remember her entrance. Dr. Cheryl Wall was the epitome of easy brilliance, grace, humility, and fierceness. She was, to use today's terminology, an unequivocal boss. They introduced themselves; and as she affirmed the generative and foundational work of her co-leader, she gently, chidingly, humorously, and pointedly reminded him and us that his classic work, Five Black Writers, published in 1970, featured essays on "five writers, all of whom were men."

Cheryl and I last met in Eatonville, Florida, in February 2019. I had not seen her in a few years, although we had kept in touch from time to time. It was the thirtieth anniversary of the Zora Neale Hurston Festival of the Arts and Humanities. As one of the leading Hurston scholars, she was of course an invited speaker. For some years prior, I had been privileged to lead several NEH Landmarks in American History teacher-training workshops for the Florida Humanities Council, on Zora Neale Hurston and her Eatonville roots (working with more than five hundred teachers from all over the country). Cheryl's inspiriting influence was with me whether planning reading materials, interviewing Eatonville residents, standing beside Zora's grave in Fort Pierce, or watching my mentor wax brilliant in the documentary we showed every year, Zora Neale Hurston: Jump at the Sun (2008).

It is said by some who I have come to love and trust while doing that work that Zora picks her literary daughters (we might think of Alice Walker here) very intentionally. Surely, Cheryl was one of Zora's daughters, preserving and forwarding her complicated, powerful, and affirming legacy, and unapologetic love of Black people, Black speech, Black culture, Black women's right to full and free expressivity. I was gifted Zora Neale Hurston by Cheryl Wall in that same class. Little did my 20-year-old Rutgers graduate student self know that nearly two decades later, while myself a professor in Miami, I would be entrusted with furthering Cheryl's work, ensuring that in Social Studies and Language Arts 
classrooms throughout the country, teachers and students would be changing words on Zora.

Cheryl and I got to hug, catch up, take pictures, laugh, and reminisce a little that day in Eatonville. I got to sit in her presence once more as her student, bearing witness once again to her largesse, her scholarly generosity, and her sheer brilliance of mind. There will never be another Cheryl Wall. Her passing has left an indescribable lacuna in the field. The best we can do by way of ending is to affirm that we, the purveyors of Black literary tradition because of her, shall carry on.

\section{Contributor's Biography}

Heather D. Russell, formerly Heather Andrade, is Professor and a Senior Associate Dean in the College of Arts, Sciences \& Education (CASE) at Florida International University. For several years she led the Florida Humanities Council's flagship seminar "Jump at the Sun: Zora Neale Hurston and her Eatonville Roots." She attended Rutgers University and attained a BA in English (1987-91) and PhD in English (1991-97) where she was taught, mentored, and trained by Dr. Cheryl A. Wall.

\section{In Memory of Cheryl Wall: A Beginning}

Evie Shockley Rutgers University

T've never faced a more difficult challenge as a writer than this one of composing 1 a brief tribute in memory of Cheryl Wall, a mentor and dear friend whose life and work meant so much to so many people. She deserves much more celebration, detail, and artful writing than I am able to muster in my current state of pandemicarrested grieving, so I offer the following as an attempt at beginning, a draft, a work-in-progress.

Cheryl Wall very materially helped make the space, the field, I entered when I started graduate school: a space that would invite me and other Black women as students, scholars, readers, and writers, without denying entry to anyone else who knew how to behave themselves. Her edited collection Changing Our Own Words: Essays on Criticism, Theory, and Writing by Black Women was one of the two volumes recommended to me as pre-reading for my return to literary studies. In the volume's introduction, she wrote: "Making our positionality explicit is not to claim a 'privileged' status for our positions. Black and white male critics have written perceptively about black women's texts. Making our positionality explicit is, rather, a response to the false universalities that long defined critical practice and rendered black women and their writing mute." Within just its first few pages, her essay cited and celebrated a whole constellation of creative and critical Black women writers whose powerful truths, formal brilliance, incisive analysis, and theoretical daring, she argued, had already forged a path through the wilderness, a path that was now 
ours to enhance, expand, and extend. Cheryl's words thus welcomed me into a space defined by work, community, and joy—not simply a space, but, in multivalent ways, a methodology, a network, and a practice of making.

She was later to welcome me into the English Department at Rutgers University: the department which she had earlier chaired, and the university at which she spent her entire career. I can never convey how fortunate I was to be mentored and befriended by Cheryl Wall. Her office was right across the hall from mine for a decade. I knocked on her open door innumerable times: to ask for her advice, to congratulate her, to compare notes on something we'd both read or seen, to share some good news, to make plans for the program (REDI) we co-directed, to see if she was free for dinner, or-did I mention this? - to ask for her advice. Over the years, from across the hall and at many other connection points, I came to see how much generosity she showed her students, how gracious and engaged she was with colleagues, how carefully she considered problem-solving strategies, how devotedly she researched and revised her scholarship_-which is to say, how tirelessly she worked. And by "tirelessly," I mean that she was unceasingly in demand and very often quite tired, but dedicated to principles of equity, resistance, change-making, and future-building that she prioritized over rest more often than not (and arguably more often than she should have, though that is for no one but her to judge).

But she also-in the process of working and on her own time-placed great emphasis on nurturing her relationships: with colleagues at Rutgers and internationally, with a wide-ranging and eclectic group of friends, with members of her church, and with cherished family. She also made time for the cultural experiences she enjoyed most: theater, music, travel, food, and, of course, the books of her favorite authors. As a result, it seemed to me, even if she was not always well rested, she was at least regularly rejuvenated in spirit. The smile of a Cheryl Wall who had been teaching Black literature in Paris or talking with sister scholars at a Black feminist symposium in Atlanta, who was describing an Aretha Franklin concert or a production of an August Wilson play, who had spent the evening with a new Toni Morrison novel or the weekend with her daughter-this was radiance.

While Cheryl taught me (and many) by her living example, she has thankfully also left a beautiful legacy - a model we can continue to aspire to-in her writing and in the memories of generations of scholars. She brought her pleasures and her values with her into the academy and worked to make it accommodate them, rather than contorting herself to fit within its pre-existing structures. She understood the significance of Black literature and culture-Black women's cultural production, in particular-and she made it her business to give and help obtain for that work the critical attention, historical contextualization, theoretical scaffolding, and institutional space it deserves. Her Women of the Harlem Renaissance, for instance, remains foundational for considerations of gender in literary studies of the period. Cheryl demonstrated repeatedly that the scholarship she produced in and for the academy could, in its register and concerns, 
simultaneously served non-academic people, whose lives often inspired Black women's cultural production and who were quite crucially among the (intended, desired) audiences for that work. I remember her noting with delight, after she published Worrying the Line: Black Women Writers, Lineage, and Literary Tradition, that church groups invited her to talk with them about the book and accounted for a number of its sales. She saw her scholarship positioned not over and apart from the creative work she studied, but alongside and in collaboration with that work. She loved the writers and thinkers she studied, and, joy of joys, she loved the hours she spent reading, teaching, and writing about their workwhich is to say that, at its core, Cheryl Wall loved her work. In this way-in all these ways-her legacy is love.

\section{Contributor's Biography}

Evie Shockley is Professor of English at Rutgers University, New Brunswick. Among her publications are Renegade Poetics: Black Aesthetics and Formal Innovation in African American Poetry (Iowa University Press, 2011), and the awardwinning poetry collection semiautomatic (Wesleyan University Press, 2017).

\section{Deborah Gray White Rutgers University}

Tmiss Cheryl as much today as I did almost a year ago. Not a day goes by that I stories about Clio and Latta, South Carolina-the two towns our people were from. We sat through Chairs meetings, and sitting together we communicated without ever opening our mouths. A throaty groan or grunt, under our breaths, was all we needed to know what we each thought about whatever was being discussed. Our body language was decipherable only to us, I think. Cheryl was gracious and elegant. She was the most generous person I will ever know, generous almost to a fault. We gave each other "just say no" cards because we were so often called upon for service work. Cheryl answered the call a whole lot more than I did and I thanked her for it because if she had not been so generous I would have had to answer more calls than I did. I only wish that she could have used her "just say no" card last April. I miss her so.

\section{Contributor's Biography}

Deborah Gray White is Board of Governors Distinguished Professor of History at Rutgers University. She is a specialist in the history of African American women; author of Ar'n't I A Woman? Female Slaves in the Plantation South (W. W. Norton, 1999) and Too Heavy a Load: Black Women in Defense of Themselves, 1894-1994 (W. W. Norton, 1999); she also is editor of Telling Histories: Black Women in the Ivory Tower (University of North Carolina Press, 2016). 


\section{Tribute to Professor Cheryl A. Wall}

\section{Magdalena J. Zaborowska University of Michigan}

Tirst met Professor Cheryl A. Wall after she had given a beautiful keynote about 1 James Baldwin's No Name in the Street (1972) at the first International James Baldwin Conference at Queen Mary's College in London in 2007. I was finishing my first book on Baldwin in Turkey then, and introduced myself afterwards, curious that she had picked as her subject the book I also found fascinating and, like her, thought rather curiously underappreciated in the field. As we chatted about Baldwin's fourth essay volume and its innovations, I felt an immediate connection to her not only as a junior colleague in African American literary studies, but also as a certain kind of reader, one who prized deep dives into the text, its cadence, imagery, and syntactic power. We were lit-crit kindred spirits. Meetings like that don't happen very often.

After that, Professor Wall became my steadfast supporter who always provided revealing and nourishing conversation whenever we encountered each other in professional settings. Dignified, charismatic, kind, and soft spoken in a way that invited listening and leaning in, she was an academic elder who invited emulation and admiration. I knew from a former graduate student, who spent her postdoc with Professor Wall at Rutgers, that she was a supportive and patient, exacting and rigorous mentor. Her books, Women of the Harlem Renaissance and Worrying the Line: Black Women Writers, Lineage, and Literary Tradition, are models of painstaking literary scholarship that few can pull off these days. They confirm the need for deep, thoughtful, close readings as the foundation of any meaningful academic work in the humanities. In that sense, she is still mentoring us and will be there for our students, which is a truly comforting thought in these days of scourge and sorrow.

On a lighter side of things: When we ran into each other on a great walking tour of Baldwin's Paris that seemed to have no end despite its advertised limit of four hours, we both hit on the same idea: We ran into a cab that had miraculously appeared in the narrow street we were walking with the group, abandoning the tour suddenly, somewhat joyously. Having apologized in unison, "So sorry, we have to get ready for the conference!" we commiserated on our way back to the hotel that we were tired and wanted to catch a breath before the evening session. It was the scary year of 2015, following the terrorist attacks in Nice and Paris, with police armed to the teeth scattered all over the city. We were attending another Baldwin conference, at the American University in Paris, and had to get through heightened security and show our passports every time we wanted to get into the conference venues. Being in the presence of likeminded folks who loved Baldwin, though, compensated for all that. The year my Me and My House book came out, we ran into each other again during the very cool, jazzy evening organized by JBR at the ASA conference in Atlanta. Professor Wall came up to me, smiling, gave me a big hug and told me how much she enjoyed my book: "Thank you for writing it!" No review gave me as much joy and pleasure. 
She was to speak about her most recent, terrific book, On Freedom and the Will to Adorn: The Art of the African American Essay, at a lecture series in Afroamerican and African Studies in April 2020 that I was running. When the University of Michigan was about to shut down due to the pandemic, we exchanged hurried emails on 14 March, confirming her lecture's unfortunate cancellation.

She wrote in response to my message:

\section{Dear Magadelena [sic!],}

I had looked forward to the lecture on April 1st but had assumed it would be canceled. All public events at Rutgers are canceled as well. I very much hope that it can be, as you say, a pleasure deferred. I would very much look forward to visiting Ann Arbor again.

These are indeed chaotic times-unlike anything I have experienced before. But there are moments of grace as well. One such moment for me was reading your review of On Freedom and the Will to Adorn in Literature and History. I could not have hoped for a more thoughtful or generous analysis of my work. I came across it at a time when I was beginning to despair that anyone would review the book. Yours was the first review-and so far the only-review I've read. What a gift. Thanks so much for the care you took in writing it.

I will miss the opportunity to continue a discussion of the African American essay with you in person next month. But I look forward to having that opportunity in the not-too-distant future.

Warm regards,

Cheryl

Then, merely two weeks later or so, I heard via friends that she had died.

Let me close this brief tribute with a few words from my review of her book that we didn't get to discuss in Ann Arbor last April, On Freedom and the Will to Adorn: The Art of the African American Essay:

Awaited eagerly by this reader, and many of those in the fields of American Literature and African American and Black Studies, this exciting book is the first (to my knowledge) comprehensive study of the cultural and stylistic foundations of the African American essay. Taking as her inspiration Zora Neale Hurston's claim that the "will to adorn" characteristic of black English changed how southern whites spoke by transforming not only their language but also their attitude toward it, Prof. Wall builds a deep and complex cultural history of the genre while offering groundbreaking theoretical analyses and interpretations of its great practitioners and shapers. A sweeping panorama that portrays the essay as a vehicle for the "subject that has preoccupied black writers for three centuries"-freedom-this book delights with rigorously researched analyses and painstaking close readings that span literary productions from the eighteenth to the twenty-first century. 
I hope you will read it.

It is still hard for me to believe that she is gone. I miss her, though I am also profoundly grateful that her work and spirit have not left us, and never will. Thank you, Professor Wall!

\section{Contributor's Biography}

Magdalena J. Zaborowska is Professor of African American and American Studies in the Departments of Afroamerican and African Studies and American Culture at University of Michigan. Her most recent books are Me and My House: James Baldwin's Last Decade in France (Duke University Press, 2018), and the MLA award-winning James Baldwin's Turkish Decade: Erotics of Exile (Duke University Press, 2009). 